Egyptian Journal of Aquatic Biology \& Fisheries

Zoology Department, Faculty of Science,

Ain Shams University, Cairo, Egypt.

ISSN $1110-6131$

Vol. 25(5): 215 - 239 (2021)

www.ejabf.journals.ekb.eg

\title{
Characterization and screening of marine-derived fungi along the coastline of Alexandria, Mediterranean Sea, Egypt
}

\section{Ahmed Gad ${ }^{1}$, Waleed B. Suleiman ${ }^{2 *}$, Ehab A. Beltagy ${ }^{1}$, Hussein El-Sheikh ${ }^{2}$, Hassan A.H. Ibrahim ${ }^{1}$}

${ }^{1}$ Marine Microbiology Department, Marine Environment Division, National Institute of Oceanography and Fisheries, Alexandria Branch, Egypt.

${ }^{2}$ Botany and Microbiology Department, Faculty of Science, Al-Azhar University, Nasr City, Cairo, Egypt.

"Corresponding Author: Email: $\underline{\text { dr_wbs@ @azhar.edu.eg }}$

\begin{tabular}{|c|c|}
\hline ARTICLE INFO & ABSTRACT \\
\hline Article History: & Egypt is considered as a white spot for fungal biodiversity thus, this study \\
\hline Received: 31 May 2021 & used ITS sequencing, and routine identification to analyze the fungal \\
\hline ed: 3 July 2021 & communities within different marine sources (sediments, water, algae, and \\
\hline : Sept. 3, 2021 & $\begin{array}{l}\text { wood) from the Egyptian Mediterranean Sea at Alexandria coastline, which } \\
\text { helped to uncover fungal diversity and distribution pattern. Two hundred }\end{array}$ \\
\hline Кеу & fifty-two marine fungal isolates were isolated from twenty-five sea sediment, \\
\hline Marine & wood samples, which were collected \\
\hline Biodiversity; & the year $2017 / 2018$ from the Egyptian \\
\hline Mediterranean Sea; & Mediterranean Sea, Alexandria, Egypt. In the present study, sediment samples \\
\hline R ; & contained the highest diversity of fungi, and the most dominant phylum was \\
\hline $\begin{array}{l}\text { PAST statistical } \\
\text { analysis. }\end{array}$ & the Ascomycota ( $90.8 \%$ OTUs) followed by the Basidiomycota (6.7\% OTUs). \\
\hline & $\begin{array}{l}\text { A small proportion of the OTUs was assigned to the Mucoromycota. Some } \\
\text { available indices had been successfully followed during this study for } \\
\text { estimating the fungal biodiversity, and these indices proved their } \\
\text { effectiveness. }\end{array}$ \\
\hline
\end{tabular}

\section{INTRODUCTION}

Fungi are ubiquitous nutrient cyclers in marine, terrestrial and freshwater ecosystems (Hassett $\boldsymbol{e t}$ al., 2019). Fungal degradation processes release $\mathrm{CO}_{2}$ to the atmosphere and into the marine food web. Heterotrophic microbes associated with the marine environment are highly dependent on dissolved organic matter produced by photosynthetic microorganisms (Kuipers et al., 2000) or they can act as biodegraders involved in the detoxification of chemical pollutants (Abdel-Razek et al., 2020). Marine fungi are an ecologically rather than taxonomically or physiologically defined group of organisms (Cavicchioli et al., 2019).

Various new compounds with interesting biological activities have been isolated from marine fungi with various biological activities (Blunt et al., 2016). Fungi had been 
classified into nine phyla, most fungi are mycelial, but yeast stages are also common (Raghukumar, 2017). Marine fungi have been classified according to morphological features as the ascomycete order Halosphaeriales comprises largely marine species with 59 genera and some 141 species (Jones, 1995). This can be roughly half of the marine ascomycetes (Kohlmeyer and Volkmann-Kohlmeyer, 1991).

Fungi are essential components of the marine ecosystem, but very little is known about their diversity and global distribution in the marine environment (Tisthammer et al., 2016). On the side, fungi play an important role as a component of the marine ecosystem, but very little is known about their diversity in the marine environments (Grossart et al., 2019). Marine fungi are active and essential players in marine biological processes across realms (Richards et al., 2012). Fungi have been recovered from nearly every marine habitat searched, including water (Gao et al., 2013), hydrothermal vents and deep-sea (Edgcomb et al., 2011), anoxic habitats, wood substrate (Jebaraj et al., 2010), as pathogens of microorganisms (Nagahama et al., 2003), associated with marine invertebrates (Yarden, 2014), and on marine plants and algae (Jones and Pang, 2012).

In general, many factors influence marine fungal community composition such as water, temperature, salinity, and location (Rämä et al., 2014), physicochemical characteristics (sulfide, total organic carbon, and dissolved inorganic carbon) (Orsi $\boldsymbol{e t}$ al., 2013), both realms and sampling date significantly differentiated fungal community composition (Guo et al., 2015), and finally environmental factors, particularly sample depth, nitrate, and oxygen. Furthermore, fungal biodiversity is essential for exploring diversity from a biogeographical perspective and view of bioactive secondary metabolites, which help to establish conservation policies (Duarte et al., 2012).

Our knowledge of marine fungi from the Egyptian shore of the Mediterranean Sea is not adequate, and this study was initiated to fill this knowledge gap. Therefore, this study is suggested to be the first to use traditional Sanger sequencing and morphology identification to comprehensively analyze the fungal communities within different marine sources (sediments, water, algae, and wood) from the Egyptian Mediterranean Sea at Alexandria coastline.

\section{MATERIALS AND METHODS}

\section{Media}

Three media were set by aged seawater and adjusted to $\mathrm{pH} 5 \pm 0.1$. They included: rose Bengal chloramphenicol agar (RCA) (Jarvis, 1973), potato dextrose agar (PDA) (Baka et al., 2015), and glucose peptone agar (Nagano et al., 2008).

\section{Study area and sample collection}

Six locations were selected for the present study; Abo Qir, Elasafra, Mohamed Nagib, Estanly, Elebrahemia, and Eastern Harbor, and they are distributed along the 
Alexandria coastline, Egyptian Mediterranean Sea, Alexandria, as shown on the map (Fig. 1). Basically, to obtain marine fungi, sampling was carried out seasonally from July 2017 to April 2018. Each season from each location, 25 sea sediment, 7 seawater, 8 algae, and 8 wood samples were randomly collected from different sampling sites. Seawater and sediment samples with depths ranging between 1.5 and $2.0 \mathrm{~m}$ which seawater were collected in $500 \mathrm{~mL}$ sterile screw-capped bottles, while sediment samples were placed in sealable sterile plastic bags underwater to prevent contamination (to reduce the likelihood of exposure to airborne spores). Wood and macroalgae samples buried deep in the sand or the sand grains were collected in sealable sterile plastic bags. All samples were directly kept on ice during transferring process to the laboratory for isolation, purification process, microscopic examination, and identification. It should avoid slow drying of samples that can cause discharge of fungal ascospores (Bremer, 2000).

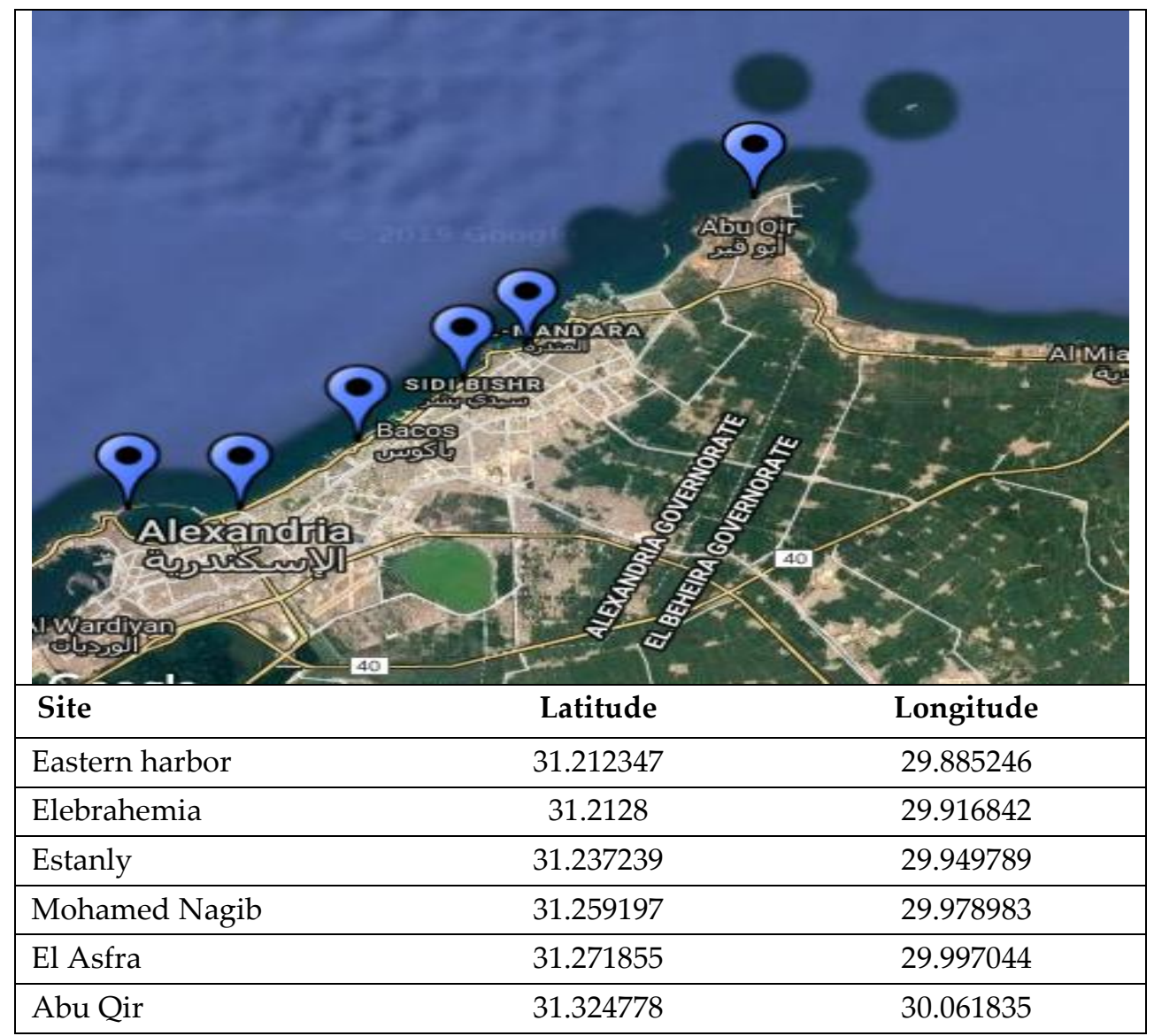

Fig. 1. The map of sampling sites distributed along the Alexandria coastline.

\section{Physicochemical analysis}

Physical and chemical analyses were carried out for the collected seawater samples to measure the following variables: temperature which measured by an ordinary 
thermometer accurate to $0.1^{\circ} \mathrm{C}$, the $\mathrm{pH}$ value, measured by a portable $\mathrm{pH}$ meter, total alkalinity, determined titrimetrically using dilute $\mathrm{HCl}$ (Nessim et al., 2005). Dissolved oxygen (DO) was analyzed through the modified Winkler method (Grasshoff et al., 2009), salinity ( $\mathrm{S} \%$ ) was calculated from the electrical conductivity of samples measured by a Beckman salinometer (Grasshoff et al., 2009).

\section{Isolation and purification of marine fungi}

One milliliter of water samples was spread directly onto the three mentioned media. Sediments samples were diluted (1:10) using sterile seawater and then one $\mathrm{mL}$ of the diluted sample was spread onto the three mentioned media. All media were autoclaved at $121^{\circ} \mathrm{C}$ for $15 \mathrm{~min}$, supplemented with antibiotics (Gentamicin $80 \mathrm{mg} / \mathrm{L}$, Piperacillin, and Tazobactam $100 \mathrm{mg} / \mathrm{L}$ ). All plates were incubated at $30{ }^{\circ} \mathrm{C}$ (Amer et al., 2019). Each thallus of algae samples was washed in sterilized seawater to remove unrefined sediments. They were homogenized in $20 \mathrm{~mL}$ of sterile filtered seawater. One $\mathrm{mL}$ of homogenate was plated onto the three mentioned media (Bremer, 2000).

All wood samples were extensively washed by sterilized seawater to remove unrefined sediments and other contaminating debris, followed by dividing into two halves and each half was subsequently disintegrated to small cubes, the first group was immersed in the three mentioned media and incubated at $30{ }^{\circ} \mathrm{C}$, while the cubes of the second group were placed in a sterile sealed plastic bag containing a paper towel wetted and examined weekly for the presence of fungal reproductive structures, with weekly spraying with sterile seawater to prevent sample desiccation. Occasionally, all samples were carried out in triplicate also, negative controls were applied during the isolation to detect true marine fungi.

\section{Characterization of the isolated marine fungi}

\section{Morphological characterization and microscopic examination}

Fungal cultures were identified based on morphological characteristics after individual isolates were transferred to $1.5 \%$ malt extract agar (Hashem et al., 2020). The macroscopic features of the cultures, such as colony color and mycelial habit, including whether the hyphae, were arial or growth within the medium (Gow and Gadd, 2007). The slides were observed under a microscope (400X) by aiding (Suleiman et al., 2019). Conidiophores, conidia, chlamydospores, and branching patterns were identified under a microscope using the identification characteristics key by (Domsch et al., 1980) and following the taxonomic arrangement described by (Hibbett et al., 2007).

\section{Molecular identification}

\section{Extraction of DNA and ITS-PCR conditions}

Fungal mycelium was inoculated in potato dextrose broth. Mycelium was harvested and converted to a fine powder in liquid nitrogen and DNA was extracted according to 
(Abd-Elsalam et al., 2007). The PCR amplifications were carried out in a total volume of $25 \mu \mathrm{L}$, containing $20 \mathrm{ng}$ genomic DNA, 1X PCR buffer, $0.2 \mathrm{mM}$ of each of dNTPs, 0.2 unit of Taq DNA polymerase (Roche Holding AG, Basel, Switzerland), and 10 pmol of the primers ITS1 (5'TCCGTAGGTGAACCTGCGG3'), ITS4 (5'TCCTCCGCTTA TTGATATGC3') (White et al., 1990; Hashem et al., 2021). The PCR amplification was carried out according to the following temperature profile: An initial step of $2 \mathrm{~min}$ at $94^{\circ} \mathrm{C}, 40 \mathrm{cycles}$ of $60 \mathrm{sec}$ at $94^{\circ} \mathrm{C}, 90 \mathrm{sec}$ at $52^{\circ} \mathrm{C}$, and $2 \mathrm{~min}$ at $72^{\circ} \mathrm{C}$, and a final step of 7 $\min$ at $72^{\circ} \mathrm{C}$.

\section{PCR products purification}

Amplified DNA was purified using AccuPrep PCR DNA Purification Kit (K-30341, Bioneer Corporation, South Korea). An aliquot of $48 \mathrm{~mL}$ of absolute ethanol was added to the washing buffer. Five volumes of buffer (PCR binding buffer) were added to one volume of PCR product ( $40 \mathrm{~mL}$ PCR product was removed and the volume was brought to $200 \mathrm{~mL}$ ) and mixed thoroughly. Then a column of binding was inserted into the Eppendorf tube and the sample was transformed into the column. $500 \mathrm{~mL}$, washing buffer was added and centrifuged for 15 minutes at $13.000 \mathrm{rpm}$ at $25{ }^{\circ} \mathrm{C}$. The excess solution was removed and the second column was transferred in a new Eppendorf tube. The binding column was put within a new Eppendorf tube, and $40 \mu \mathrm{L}$ samples were inserted in sterile distilled water two times in the middle column of binding placed on a metal rack were to remain constant. Tube and binding column were centrifuged for 15 min at $10.000 \mathrm{rpm}$. The column was removed and the DNA purified was collected in tubes at $-20^{\circ} \mathrm{C}$ for subsequent studies (Hussain et al., 2018).

\section{Sequencing and analysis}

The PCR products were purified with the ExoSAP method and Sanger sequencing with PCR primers was performed at Macrogen Incorporation (Seoul, South Korea). The sequences were assembled using the DNA STAR SeqMan (DNA STAR Incorporation, Wisconsin, USA), and to establish the quality control of generated ITS sequences we have applied the guidelines listed by (Nilsson et al., 2012). Generated sequences firstly were submitted to the GenBank database. Sequence analyses obtained by BLASTN similarity search at the website (http://www.ncbi.nlm.nih.gov/BLAST) and secondly were multiply aligned using MEGA_X_10.1.6 software and the phylogenetic tree (Neighbor-joining) constructed by maximum- likelihood method with rapid 5,000 bootstrapping replicates. At last, species-level OTUs (Blaxter et al., 2005) were determined based on a 97\% sequence similarity cut-off threshold, which is inside the range of intraspecific ITS sequence similarity. 


\section{Statistical analyses}

For the diversity indices (Species richness (S), Total number of individuals, Dominance_D, Simpson_1-D, Shannon_H, Evenness_e^H/S, Brillouin, Menhinick, Margalef, Equitability_J, Fisher_alpha, Berger-Parker, and Chao-1), PAST software version 3.15 (copyright Hammer \& Harper, Natural History Museum, University of Oslo, Norway) was used. In our study, several estimates of total species number were used to confirmed the reliability of estimates richness (S) according to extrapolations from species richness values, namely Chao's method, first and second Jackknife and Bootstrap for each species using PAST software version 3.15 (Hammer et al., 2001) and matched them with observed total species number (Oksanen et al., 2012).

\section{RESULTS AND DISCUSSION}

\section{Characterization of collected samples}

The physicochemical properties included temperature, $\mathrm{pH}$, salinity, alkalinity, and dissolved oxygen were significant predictors of the marine fungal community which played an essential role in the structuring of the marine fungal environments (Tisthammer et al., 2016). However, the seasonal regional variations of different physicochemical water characteristics in the sex areas of sample collection during the four seasons are given in Table 1.

Variations in water temperature depend on sampling time, climatic conditions, position and mean the daily number of sunshine hours and also affected by turbidity, humidity, and wind force (Ivanov et al., 2007). As expected, high water temperatures were observed during the warm period from July to September. It is well established that the ranges of water temperature significantly affected the changes in physicochemical parameters. Temperature variations decreased from summer $\left(28-29.2^{\circ} \mathrm{C}\right)$ through autumn $\left(23.9-24.4^{\circ} \mathrm{C}\right)$ reaching the minimum level during winter $\left(14.8-15.5^{\circ} \mathrm{C}\right)$ and increase again during spring $\left(26.1-26.7^{\circ} \mathrm{C}\right)$.

The increase and decrease of $\mathrm{pH}$ values coincided with the drop in oxygen content due to the effect of discharge of brackish water (Abdel-Halim and Aly-Eldeen, 2016). The surface water $\mathrm{pH}$ varied seasonally from a minimum of 7.40 in winter to 8.07 in summer. Salinity was measured seawater dilution mainly caused by land-based source subsequently and discharge, which reflects the degree of aquatic contamination in the marine environment (Zyadah $\boldsymbol{e t}$ al., 2004). Salinity values of the study area increased from winter $33.71 \%$ through spring $40.63 \%$ reaching a maximum level of $41.25 \%$ during summer. Increases in the spring-summer period may have been the result of evaporation (Kükrer and Mutlu, 2019). Dissolved oxygen is very essential to the respiratory metabolism of most aquatic organisms. It affects the availability and solubility of nutrients, low levels of dissolved oxygen facilitate the release of nutrients from the sediments and therefore affects the productivity of aquatic ecosystems (Abdelmongy and 
El-Moselhy, 2015). The dissolved oxygen values ranged from 3.73 to $7.68 \mathrm{mg} / \mathrm{L}$ in summer with an average value of $4.81 \mathrm{ml} / \mathrm{L}$ and from 3.42 to $7.85 \mathrm{mg} / \mathrm{L}$ in Autumn with an average value of $4.89 \mathrm{mg} / \mathrm{L}$ and from 4.54 to $8.98 \mathrm{mg} / \mathrm{L}$ in Winter with an average value of $5.99 \mathrm{mg} / \mathrm{L}$ and from 3.42 to $7.98 \mathrm{mg} / \mathrm{L}$ in Spring with an average value of 5.1 $\mathrm{mg} / \mathrm{L}$.

Table 1. Seasonal variations of different hydrographical parameters at different sites along the study area.

\begin{tabular}{|c|c|c|c|c|c|c|c|}
\hline \multirow[b]{2}{*}{ Region/variable } & \multicolumn{7}{|c|}{ Season } \\
\hline & Summer & Autumn & Winter & Spring & Min. & Max. & Mean \\
\hline \multicolumn{8}{|l|}{ Temperature $\left({ }^{\circ} \mathrm{C}\right)$ : } \\
\hline Abu Qir & $28.0 \pm 0.13$ & $23.9 \pm 0.22$ & $14.8 \pm 0.13$ & $26.1 \pm 0.23$ & $14.8 \pm 0.13$ & $28.0 \pm 0.13$ & $23.3 \pm 0.17$ \\
\hline Elasafra & $28.2 \pm 0.22$ & $23.9 \pm 0.13$ & $15.0 \pm 0.20$ & $26.2 \pm 0.15$ & $15 \pm 0.20$ & $28.2 \pm 0.22$ & $23.37 \pm 0.17$ \\
\hline Mohamed Nagib & $28.0 \pm 0.37$ & $24.2 \pm 0.12$ & $15.4 \pm 0.33$ & $26.6 \pm 0.16$ & $15.4 \pm 0.33$ & $28.0 \pm 0.37$ & $23.55 \pm 0.24$ \\
\hline Estanly & $28.3 \pm 0.34$ & $24.3 \pm 0.25$ & $15.3 \pm 0.24$ & $26.6 \pm 0.37$ & $15.3 \pm 0.24$ & $28.3 \pm 0.34$ & $23.62 \pm 0.3$ \\
\hline Elebrahemia & $29.0 \pm 0.29$ & $24.4 \pm 0.13$ & $15.5 \pm 0.12$ & $26.6 \pm 0.23$ & $15.5 \pm 0.12$ & $29.0 \pm 0.29$ & $23.95 \pm 0.19$ \\
\hline Eastern Harbor & $29.2 \pm 0.23$ & $24.4 \pm 0.15$ & $15.5 \pm 0.10$ & $26.7 \pm 0.22$ & $15.5 \pm 0.10$ & $29.2 \pm 0.23$ & $24.0 \pm 0.17$ \\
\hline Min. & $28.0 \pm 0.13$ & $23.9 \pm 0.13$ & $14.8 \pm 0.13$ & $26.1 \pm 0.23$ & & & \\
\hline Max. & $29.2 \pm 0.23$ & $24.4 \pm 0.13$ & $15.5 \pm 0.12$ & $26.7 \pm 0.22$ & & & \\
\hline Mean & $28.4 \pm 0.26$ & $24.1 \pm 0.16$ & $15.4 \pm 0.18$ & $26.4 \pm 0.22$ & & & \\
\hline \multicolumn{8}{|l|}{ pH value: } \\
\hline Abu Qir & $8.01 \pm 0.02$ & $7.71 \pm 0.12$ & $7.45 \pm 0.06$ & $7.91 \pm 0.23$ & $7.45 \pm 0.06$ & $8.01 \pm 0.02$ & $7.77 \pm 0.1$ \\
\hline Elasafra & $7.91 \pm 0.08$ & $7.82 \pm 0.23$ & $7.42 \pm 0.09$ & $7.92 \pm 0.12$ & $.42 \pm 0.09$ & $7.92 \pm 0.12$ & $7.76 \pm 0.13$ \\
\hline Mohamed Nagib & $8.03 \pm 0.03$ & $7.76 \pm 0.52$ & $7.40 \pm 0.07$ & $7.95 \pm 0.14$ & $7.40 \pm 0.07$ & $8.03 \pm 0.03$ & $7.78 \pm 0.19$ \\
\hline Estanly & $7.9 \pm 0.13$ & $7.8 \pm 0.08$ & $7.45 \pm 0.32$ & $8.01 \pm 0.02$ & $7.45 \pm 0.32$ & $8.01 \pm 0.02$ & $7.79 \pm 0.13$ \\
\hline Elebrahemia & $8.07 \pm 0.03$ & $7.82 \pm 0.05$ & $7.41 \pm 0.13$ & $7.98 \pm 0.19$ & $7.41 \pm 0.13$ & $8.07 \pm 0.03$ & $7.82 \pm 0.1$ \\
\hline Eastern Harbor & $8.03 \pm 0.02$ & $7.85 \pm 0.04$ & $7.4 \pm 0.12$ & $7.94 \pm 0.27$ & $7.4 \pm 0.12$ & $8.03 \pm 0.02$ & $7.80 \pm 0.11$ \\
\hline Min. & $7.91 \pm 0.08$ & $7.71 \pm 0.12$ & $7.40 \pm 0.07$ & $7.91 \pm 0.23$ & & & \\
\hline Max. & $8.07 \pm 0.03$ & $7.85 \pm 0.04$ & $7.45 \pm 0.32$ & $8.01 \pm 0.02$ & & & \\
\hline Mean & $7.99 \pm 0.08$ & $7.79 \pm 0.17$ & $7.42 \pm 0.13$ & $7.95 \pm 0.16$ & & & \\
\hline \multicolumn{8}{|l|}{ Salinity (\%): } \\
\hline Abu Qir & $40.81 \pm 0.7$ & $38.1 \pm 0.22$ & $38.6 \pm 0.83$ & $39.8 \pm 0.41$ & $38.1 \pm 0.22$ & $40.8 \pm 0.71$ & $39.35 \pm 0.54$ \\
\hline Elasafra & $40.5 \pm 0.52$ & $38.9 \pm 0.34$ & $39.09 \pm 0.2$ & $39.6 \pm 0.39$ & $38.92 \pm 0.3$ & $40.53 \pm 0.5$ & $39.55 \pm 0.36$ \\
\hline Mohamed Nagib & $41.2 \pm 0.93$ & $39.1 \pm 0.13$ & $40.04 \pm 0.9$ & $40.6 \pm 0.73$ & $39.1 \pm 0.13$ & $41.25 \pm 0.9$ & $40.25 \pm 0.68$ \\
\hline Estanly & $40.9 \pm 0.32$ & $38.8 \pm 0.36$ & $39.19 \pm 0.6$ & $40.42 \pm 0.9$ & $38.8 \pm 0.36$ & $40.9 \pm 0.32$ & $39.82 \pm 0.56$ \\
\hline Elebrahemia & $39.98 \pm 0.4$ & $38.3 \pm 0.52$ & $38.74 \pm 0.6$ & $39.8 \pm 0.67$ & $38.3 \pm 0.52$ & $39.98 \pm 0.4$ & $39.2 \pm 0.57$ \\
\hline Eastern Harbor & $38.93 \pm 0.9$ & $35.83 \pm 0.5$ & $33.71 \pm 0.4$ & $36.6 \pm 0.44$ & $35.83 \pm 0.5$ & $38.93 \pm 0.9$ & $36.26 \pm 0.58$ \\
\hline Min. & $38.93 \pm 0.9$ & $35.83 \pm 0.5$ & $33.71 \pm 0.4$ & $36.6 \pm 0.44$ & & & \\
\hline Max. & $41.25 \pm 0.9$ & $39.1 \pm 0.13$ & $40.04 \pm 0.9$ & $40.63 \pm 0.7$ & & & \\
\hline Mean & $40.4 \pm 0.60$ & $38.17 \pm 0.3$ & $38.24 \pm 0.6$ & $39.49 \pm 0.5$ & & & \\
\hline \multicolumn{8}{|l|}{ Alkalinity (meq/L): } \\
\hline Abu Qir & $2.65 \pm 0.21$ & $2.58 \pm 0.29$ & $3.1 \pm 0.23$ & $2.74 \pm 0.42$ & $2.58 \pm 0.29$ & $3.1 \pm 0.23$ & $2.76 \pm 0.28$ \\
\hline Elasafra & $2.92 \pm 0.09$ & $2.71 \pm 0.21$ & $2.54 \pm 0.09$ & $2.91 \pm 0.43$ & $2.54 \pm 0.09$ & $2.92 \pm 0.09$ & $2.77 \pm 0.18$ \\
\hline Mohamed Nagib & $2.62 \pm 0.31$ & $2.69 \pm 0.1$ & $2.46 \pm 0.12$ & $2.87 \pm 0.32$ & $2.46 \pm 0.12$ & $2.87 \pm 0.32$ & $2.66 \pm 0.21$ \\
\hline Estanly & $2.6 \pm 0.23$ & $2.51 \pm 0.1$ & $2.32 \pm 0.31$ & $2.64 \pm 0.24$ & $2.32 \pm 0.31$ & $2.64 \pm 0.24$ & $2.51 \pm 0.22$ \\
\hline Elebrahemia & $2.59 \pm 0.12$ & $2.56 \pm 0.02$ & $2.36 \pm 0.07$ & $2.73 \pm 0.12$ & $2.36 \pm 0.07$ & $2.73 \pm 0.12$ & $2.56 \pm 0.08$ \\
\hline Eastern Harbor & $2.61 \pm 0.31$ & $2.5 \pm 0.03$ & $2.35 \pm 0.12$ & $2.65 \pm 0.21$ & $2.35 \pm 0.12$ & $2.65 \pm 0.21$ & $2.52 \pm 0.16$ \\
\hline Min. & $2.59 \pm 0.12$ & $2.5 \pm 0.03$ & $2.36 \pm 0.07$ & $2.73 \pm 0.12$ & & & \\
\hline Max. & $2.92 \pm 0.09$ & $2.71 \pm 0.21$ & $2.54 \pm 0.09$ & $2.91 \pm 0.43$ & & & \\
\hline Mean & $2.66 \pm 0.21$ & $2.59 \pm 0.12$ & $2.52 \pm 0.15$ & $2.75 \pm 0.29$ & & & \\
\hline \multicolumn{8}{|c|}{ Dissolved oxygen (mg/L): } \\
\hline Abu Qir & $7.68 \pm 0.93$ & $7.85 \pm 0.70$ & $8.98 \pm 0.97$ & $7.98 \pm 0.32$ & $7.68 \pm 0.9$ & $8.98 \pm 0.9$ & $8.12 \pm 0.73$ \\
\hline Elasafra & $3.73 \pm 0.43$ & $3.42 \pm 0.83$ & $4.54 \pm 0.95$ & $3.42 \pm 0.56$ & $3.42 \pm 0.56$ & $4.54 \pm 0.9$ & $3.77 \pm 0.71$ \\
\hline Mohamed Nagib & $3.74 \pm 0.86$ & $3.6 \pm 0.93$ & $5.32 \pm 0.56$ & $4.06 \pm 0.67$ & $3.6 \pm 0.93$ & $5.32 \pm 0.56$ & $4.18 \pm 0.75$ \\
\hline
\end{tabular}




\begin{tabular}{|c|c|c|c|c|c|c|c|}
\hline Estanly & $4.65 \pm 1.02$ & $4.12 \pm 0.82$ & $5.21 \pm 0.76$ & $3.95 \pm 0.55$ & $3.95 \pm 0.55$ & $5.21 \pm 0.76$ & $4.48 \pm 0.53$ \\
\hline Elebrahemia & $4.07 \pm 0.84$ & $3.84 \pm 0.62$ & $5.9 \pm 0.96$ & $4.26 \pm 0.45$ & $3.84 \pm 0.62$ & $5.9 \pm 0.96$ & $4.51 \pm \mathbf{0 . 7 1}$ \\
\hline Eastern Harbor & $5.01 \pm 0.53$ & $6.54 \pm 0.61$ & $6.02 \pm 1.03$ & $6.97 \pm 0.35$ & $5.01 \pm 0.53$ & $6.97 \pm 0.35$ & $6.13 \pm 0.38$ \\
\hline Min. & $3.73 \pm 0.43$ & $3.42 \pm 0.88$ & $4.54 \pm 0.98$ & $3.42 \pm 0.56$ & & & \\
\hline Max. & $7.68 \pm 0.92$ & $7.85 \pm 0.76$ & $8.98 \pm 0.92$ & $7.98 \pm 0.32$ & & & \\
\hline Mean & $4.81 \pm 0.60$ & $4.89 \pm 0.75$ & $5.99 \pm 0.87$ & $5.10 \pm 0.49$ & & & \\
\hline
\end{tabular}

The highest values during spring and winter may be related to the decrease in the air temperature leading to an increase in the solubility of the photosynthetic activity, and the atmospheric oxygen due to the abundance of phytoplankton (Ali and Khairy, 2016). Alkalinity is affected by several factors as respiration and photosynthesis, nitrification, denitrification, sulfide reduction, sulfide oxidation, and $\mathrm{CaCO}_{3}$ dissolution (Saad et al., 2017). Total alkalinity in the surface water of the study area ranged from 2.59 to 2.92 meq/L in summer with an average value of $2.66 \mathrm{meq} / \mathrm{L}$ and from 2.5 to $2.71 \mathrm{meq} / \mathrm{L}$ in Autumn with an average value of $2.59 \mathrm{meq} / \mathrm{L}$ and from 2.32 to $3.1 \mathrm{meq} / \mathrm{L}$ in Winter with an average value of $2.52 \mathrm{meq} / \mathrm{L}$ and from 2.64 to $2.91 \mathrm{meq} / \mathrm{L}$ in Spring.

\section{Isolation and screening of marine fungi}

This study is considered the first to use traditional Sanger sequencing and morphology identification to comprehensively analyze the fungal communities within different marine sources (sediments, water, algae, and wood) from the Egyptian Mediterranean Sea at Alexandria coastline, which helps to uncover fungal diversity and distribution patterns in marine sources of the Alexandria coastline. Fungi are essential components of marine ecosystems, when marine fungi strains are compared to strains of terrestrial fungi, they will be frequently overlooked and poorly understood (Gladfelter $\boldsymbol{e t}$ al., 2019).

Based on locations, 252 marine fungal isolates were isolated from twenty-five sea sediments, seven water, eight algae, and eight wood samples which were collected seasonally through sex trips during the year 2017/2018 from the Mediterranean Sea, Alexandria, Egypt. The six locations selected for this study included Abu Qir, Elasafra, Mohamed Nagib, Estanly, Elebrahemia, and Eastern Harbor. Also, based on the percentage of locations, the most common fungal isolates were isolated from Abu Qir (33.73\%), Elebrahemia (19.44\%), Elasafra (19.05\%), Estanly (15.48\%), Mohamed Nagib (7.14\%), and Eastern Harbor (5.16\%) (Table 2). Abu Qir harbored more numbers fungal taxa than the other stations, suggesting that it may be more polluted.

The sediment samples generated 145 fungal isolates (57.54\%), 46 fungal isolates (18.25\%) were obtained from the water samples, 34 fungal isolates (13.49\%), 46 were obtained from the algae samples and 27 fungal isolates $(10.71 \%)$ were generated from the wood samples (Table 2). Previous investigators also have found that fungal taxa in seawater were low (Amer et al., 2019). Fungi are very successful inhabitants in soil (Frąc et al., 2018). Correspondingly, in our study sediment samples have the highest diversity of fungi. A similar result (Lee et al., 2019) had been observed when investigating the marine fungal communities associated with the mangrove tree Avicennia 
alba throughout Peninsular, Malaysia, and Singapore where the sediment showed high numbers of fungal taxa. The most likely explanation is that the sediment-rich with organic and inorganic compounds that increases the fungal community.

For wood and algae, samples with a softened and roughened surface may suitable for the fungal growth while, the sandy beaches, macroalgae, and wood buried in the grains of the sand occurring near these organic substrata are idealistic (Overy et al., 2019). However, two different algal species were collected and identified as; Ulva lacttuca (green algae) and Surgassum acinaciforme (brown algae).

Table 2. The different percentages of fungal isolates from different locations and sources along the coastline of Alexandria, Mediterranean Sea, Egypt, (total number of isolates are 252).

\begin{tabular}{lccc}
\hline Locations & \% of fungal isolates & Samples & \% of fungal isolates \\
\hline Eastern Harbor & 5.16 & Sediment & 57.54 \\
\hline Elebrahemia & 19.44 & Water & 18.25 \\
\hline Estanly & 15.48 & Algae & 13.49 \\
\hline Mohammed Nagib & 7.14 & Wood & 10.71 \\
\cline { 1 - 2 } Elasafra & 19.05 & & \\
\cline { 1 - 2 } Abu Qir & 33.73 & & \\
\cline { 1 - 2 }
\end{tabular}

\section{Preliminary identification of marine fungal isolates}

The identifications of the 252 marine fungal isolates were initially based on gross macroscopic features as colony color and mycelial habit, including whether the hyphae were arial or growth was within the medium. Characterization of the isolated marine fungi indicated that 252 comprising 27 species of fungi. Microscopic examination is very essential in identifying or confirming the classification of the isolated fungus especially at the point of initial inoculation (Overy et al., 2019).

The isolated fungi were examined based on cultural, microscopic, and morphological characteristics. Data in Fig. 2, show 27 fungal species isolated and identified. In this study, microscopic examination showed that members of the phylum Ascomycota were the most common group in this study. Twenty-two fungal species belonged to this group, while four fungal species belonged to Basidiomycota, and one only fungal species belonged to Mucoromycota. Ascomycota is the largest group of the Kingdom Mycetae with more than 32,000 species, of which more than 500 species are obligate marine origin (Raghukumar, 2017). A similar result (Abdel-Wahab et al., 2019) had been observed in the Red Sea mangroves in Saudi Arabia, twelve fungal isolates often belong to ascomycetes (ten ascomycetes, one basidiomycete, and one asexual fungus). 


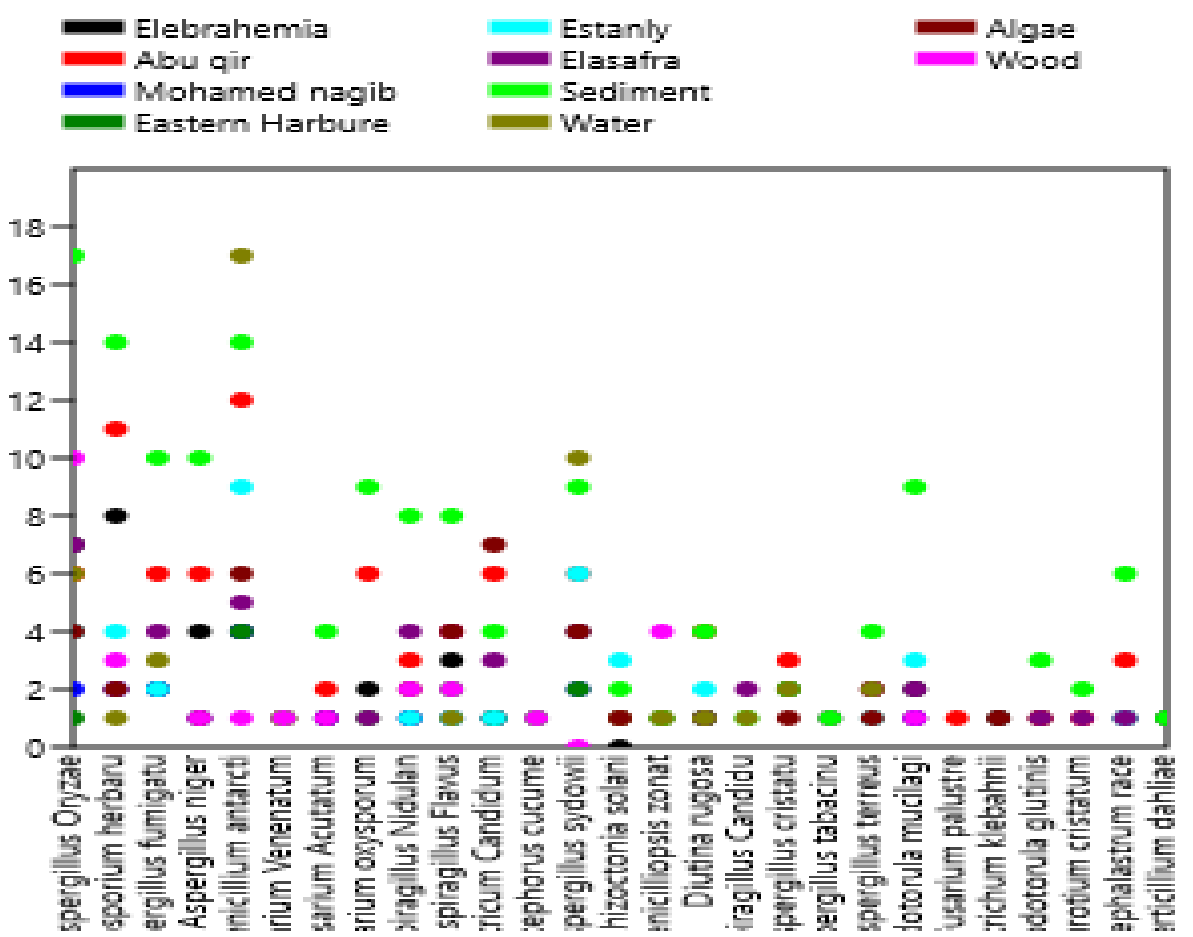

Fig. 2. Fungal species isolated and identified according to microscopic and morphological characteristics.

\subsection{Numerical classification of marine fungal isolates}

Representatives of all fungal morphotypes observed from each sample were picked from primary isolation. 252 colonies were selected for numerical classification according to location, sources of samples, macroscopic and microscopic examination. The similarity matrix was constructed based on the positive or negative location, sources of samples, macroscopic and microscopic examination test for each isolate which was scored as 1 and 0 , respectively (Fig. 3). The cluster analysis of 35 isolates was carried out using PRIMER $\mathrm{MeV}$ 4.9.0 software according to their various characters. The dendrogram for 252 isolates was carried out using MEGA_X_10.1.6 software. Traditionally, numerical taxonomy according to morphological and physiological descriptions has been applied for fungal taxonomy leading to reliable improvements in isolates identification (Amer $\boldsymbol{e t}$ al., 2019). 


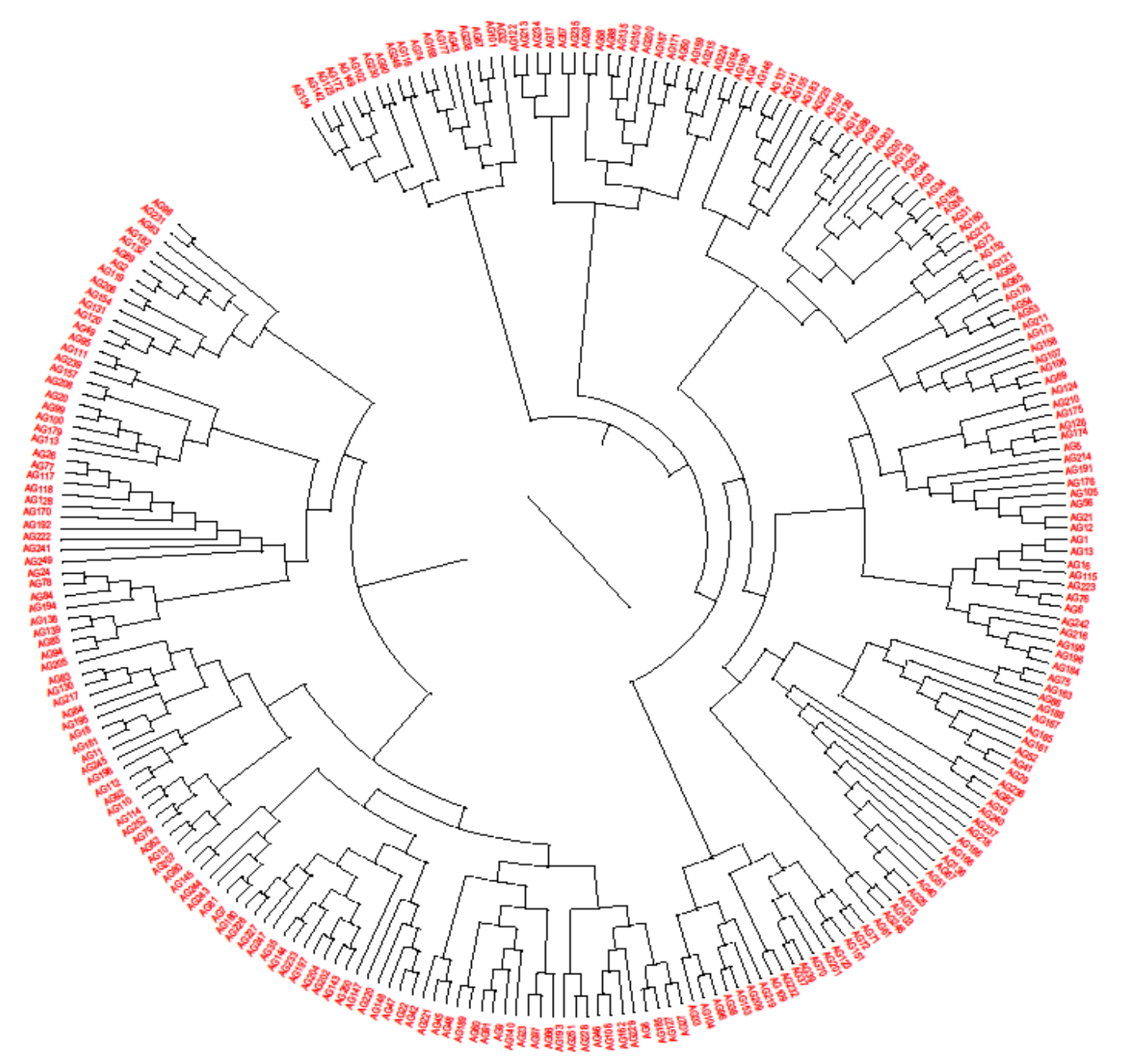

Fig. 3. Simplified dendrogram showing the relationship between fungal isolates using MEGA_X_10.1.6 software.

\subsection{Isolates identification}

\section{- ITS sequences}

The sequences of ITS-PCR products of 27 fungal isolates were obtained which helped in identification to the species level (Arif et al., 2013) (Table 3). Based on their similarity with ITS sequences obtained from GenBank, good quality ITS sequences could be confidently separated into five subphyla: Pezizomycotina, Saccharomycotina, Mucoromycotina, Agaricomycotina, and Pucciniomycotina.

ITS sequences from nineteen isolates in the subphylum Pezizomycotina were obtained, all of which were of good quality and formed contigs ranging from 437 to 811 base in length. ITS sequences from three isolates in the subphylum Saccharomycotina were obtained and formed contigs ranging from 389 to 696 bases. ITS sequences from 
two isolates in the subphylum Agaricomycotina and Pucciniomycotina were obtained, which formed contigs 586, 591, and 679, 503 bases in length respectively. Only one isolate in the subphylum Mucoromycotina was obtained, which was formed contigs 617 bases in length. The current results indicated that Pezizomycotina was the most abundant subphyla. Similar results were obtained with previous studies that find that Pezizomycotina tends to dominate marine habitats (Crous et al., 2009).

The identification of fungus isolated during this investigation was based on ITS sequence data and typically supported by morphological observations; morphological features of fungus isolates were generally in agreement with descriptions of corresponding fungus type strains. Describing fungal cell morphology at a microscopic level limited the extent to which morphological observations were able to support the identification of fungal isolates.

Table 3. Isolates identification based on GenBank search results and phylogenetic analysis using ITS sequence data.

\begin{tabular}{|c|c|c|c|c|c|c|}
\hline \multirow[b]{2}{*}{ Subphylum } & \multicolumn{5}{|c|}{ Highest identity sequence from GenBank } & \multirow{2}{*}{$\begin{array}{c}\text { The closest } \\
\text { neighboring organism } \\
\text { from the phylogenetic } \\
\text { tree }\end{array}$} \\
\hline & $\begin{array}{c}\text { Partial } \\
\text { ITS } \\
\text { sequence } \\
\text { (bases) }\end{array}$ & $\begin{array}{l}\text { Accession } \\
\text { number }\end{array}$ & $\begin{array}{c}\text { E- } \\
\text { Value }\end{array}$ & $\begin{array}{c}\text { Query } \\
\text { cover } \\
(\%)\end{array}$ & $\begin{array}{c}\text { Identity } \\
(\%)\end{array}$ & \\
\hline Saccharomycotina & 696 & MN638741.1 & 0.0 & 100 & 100 & Geotrichum candidum \\
\hline Pezizomycotina & 550 & MW668463.1 & 0.0 & 100 & 100 & Penicillium antarcticum \\
\hline Mucoromycotina & 617 & MN638743.1 & 0.0 & 100 & 98.70 & Syncephalastrum racemosun \\
\hline Agaricomycotina & 586 & MW668464.1 & 0.0 & 100 & 97.95 & Thanatephorus cucumeris \\
\hline Pezizomycotina & 507 & MN638745.1 & 0.0 & 100 & 99.21 & Fusarium venenatum \\
\hline Pezizomycotina & 558 & MN638746.1 & 0.0 & 100 & 99.1 & Fusarium acutatum \\
\hline Pezizomycotina & 811 & MN638747.1 & 0.0 & 100 & 98.52 & Aspergillus oryzae \\
\hline Pezizomycotina & 516 & MN638748.1 & 0.0 & 99 & 99.61 & Fusarium oxysporum \\
\hline Agaricomycotina & 591 & MN638749.1 & 0.0 & 99 & 98.52 & Rhizoctonia solani \\
\hline Pucciniomycotina & 679 & MN638750.1 & 0.0 & 100 & 100 & Rhodotorula mucilaginosa \\
\hline Pezizomycotina & 518 & MN638751.1 & 0.0 & 100 & 100 & Cladosporium herbarum \\
\hline Pezizomycotina & 554 & MN638752.1 & 0.0 & 100 & 97.11 & Aspergillus terreus \\
\hline Pezizomycotina & 590 & MN638753.1 & 0.0 & 98 & 99.49 & Aspergillus niger \\
\hline Pezizomycotina & 622 & MN638754.1 & 0.0 & 100 & 100 & Aspergillus fumigatus \\
\hline Pezizomycotina & 513 & MN871428.1 & 0.0 & 100 & 99.42 & Aspergillus cristatus \\
\hline Pezizomycotina & 609 & MW668465.1 & 0.0 & 98 & 96.66 & Aspergillus sydowii \\
\hline Pezizomycotina & 783 & MW668466.1 & 0.0 & 99 & 98.59 & Aspergillus nidulans \\
\hline Pezizomycotina & 549 & MW668467.1 & 0.0 & 99 & 92.54 & Aspergillus flavus \\
\hline Pezizomycotina & 437 & MW668468.1 & 0.0 & 96 & 96.99 & Penicilliopsis zonata \\
\hline Saccharomycotina & 389 & MW668469.1 & 0.0 & 97 & 99.47 & Diutina rugosa \\
\hline Pezizomycotina & 464 & MW668470.1 & 0.0 & 100 & 99.57 & Aspergillus candidus \\
\hline Pezizomycotina & 561 & MW668476.1 & 0.0 & 99 & 99.28 & Aspergillus tabacinus \\
\hline Pezizomycotina & 502 & MW668472.1 & 0.0 & 96 & 96.40 & Fusarium palustre \\
\hline Pucciniomycotina & 503 & MW668474.1 & 0.0 & 99 & 95.47 & Rhodotorula glutinis \\
\hline Saccharomycotina & 423 & MW668473.1 & 0.0 & 99 & 99.18 & Geotrichum klebahnii \\
\hline Pezizomycotina & 552 & MW668477.1 & 0.0 & 96 & 97.6 & Verticillium dahliae \\
\hline Pezizomycotina & 529 & MW668475.1 & 0.0 & 97 & 96.41 & Eurotium cristatum \\
\hline
\end{tabular}




\section{- Phylogenetic analysis}

Phylogenetic studies have been facilitated by DNA marker technologies, which offer a number of insensitive genetic markers such as random amplified polymorphic DNA, amplified fragment length polymorphism, and intersample sequence repeat (Das $\boldsymbol{e t}$ al., 2017). Phylogenetic studies of genera and species within fungi based on the sequence variability amongst 5.8S ribosomal RNA genes and internal transcribed spacer are widely used (El-Sheikh et al., 2014). Phylogenetic analysis was carried out using ITS sequences from a fungus isolated during this investigation and selected ITS sequences from GenBank search results. For each isolate with good quality ITS sequence data, a comparison was made between GenBank search results and the closest neighboring organism from phylogenetic trees (Fig. 4, Table 3).

All the isolates which were identified based on traditional, phenotypic methods were confirmed by molecular methods. The sizes of obtained PCR products were in the range of 389-811 bases. Results of molecular identification were completely consistent with those obtained by traditional methods. All the nucleotide sequences obtained with primers ITS1 and ITS4 together with the corresponding sequences to which these showed the closest match are deposited in GenBank under accession numbers. A BLAST search queried good quality ITS sequences from 27 isolates against the sequence database GenBank, and most sequences yielded BLAST results with high sequence identity (92.54-100\%) and the Evalues were zero (0.0). For some ITS sequences, the BLAST result with the highest sequence identity was from a named species, allowing confident identification of the corresponding isolate based on GenBank search results alone. 


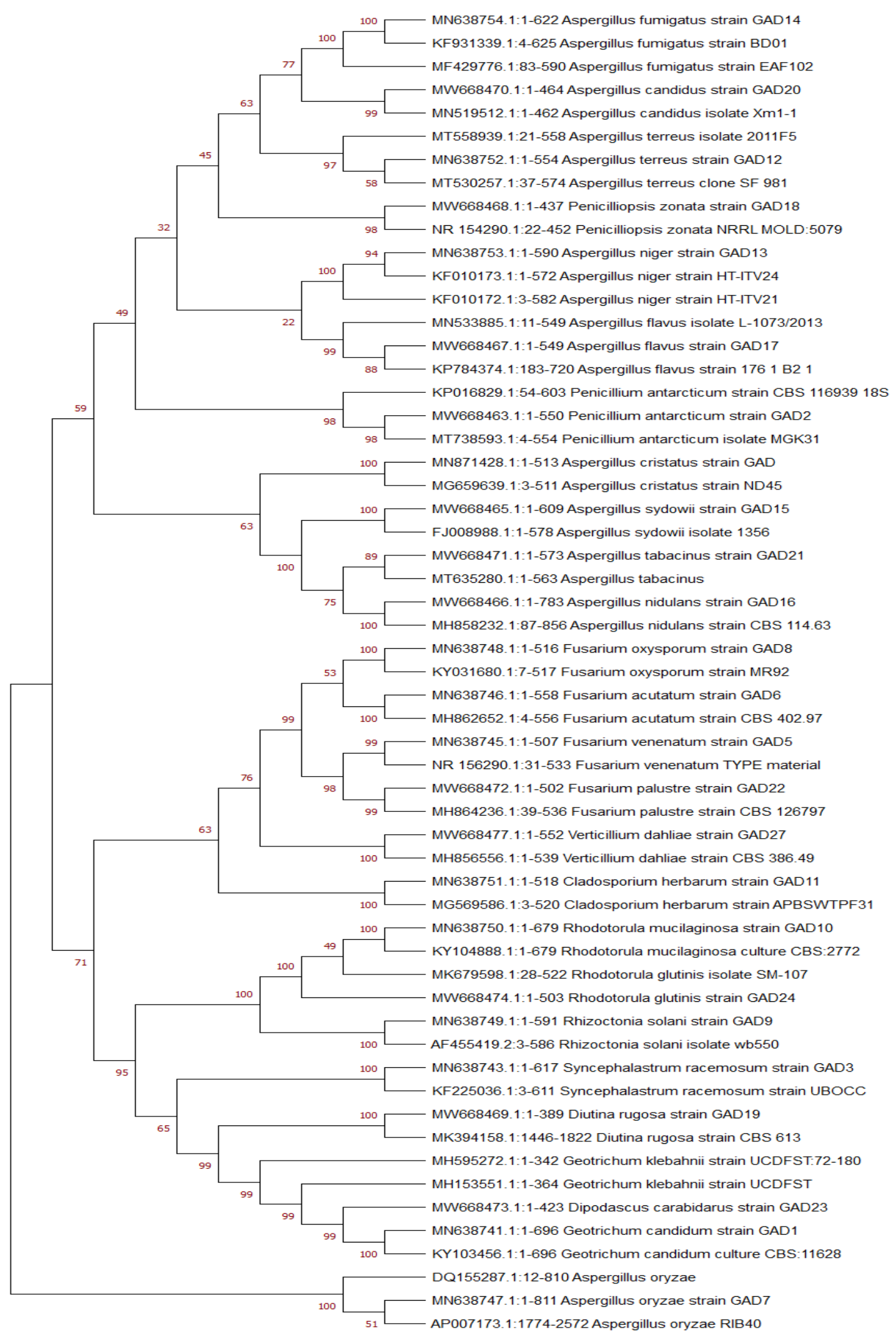

Fig. 4. Phylogenic tree of marine isolates using ITS sequence data. 


\section{Distribution of fungal isolates}

Marine fungi are worldwide in distribution but certain taxa may be restricted geographically to the tropics, temperate, subtropics, or polar waters (Schmit, 2003). The Mediterranean Sea is connected to the Atlantic Ocean and is considered a part of it. Tropical marine fungi are known from the Atlantic, Pacific Oceans, and Indian, from a wide range of substrates, supporting the greatest diversity (Hassett et al., 2020). However, there is little overlap between temperate and tropical regions in fungal species (Bennett and Classen, 2020).

The distribution of the isolated species from variance locations is shown in (Fig. 5). The results showed that Aspergillus oryzae, Penicillium antarcticum, Cladosporium herbarum, aspergillus flavus, Aspergillus fumigatus, and Aspergillus sydowii were the most distributed species, and they were isolated from all locations, while Thanatephorus cucumeris, Aspergillus Candidus, and Aspergillus tabacinus were isolated only from Elasafra, Fusarium palustre was isolated from the Abu Qir only, while Geotrichum klebahnii and Verticillium dahliae were isolated only from Elebrahemia.

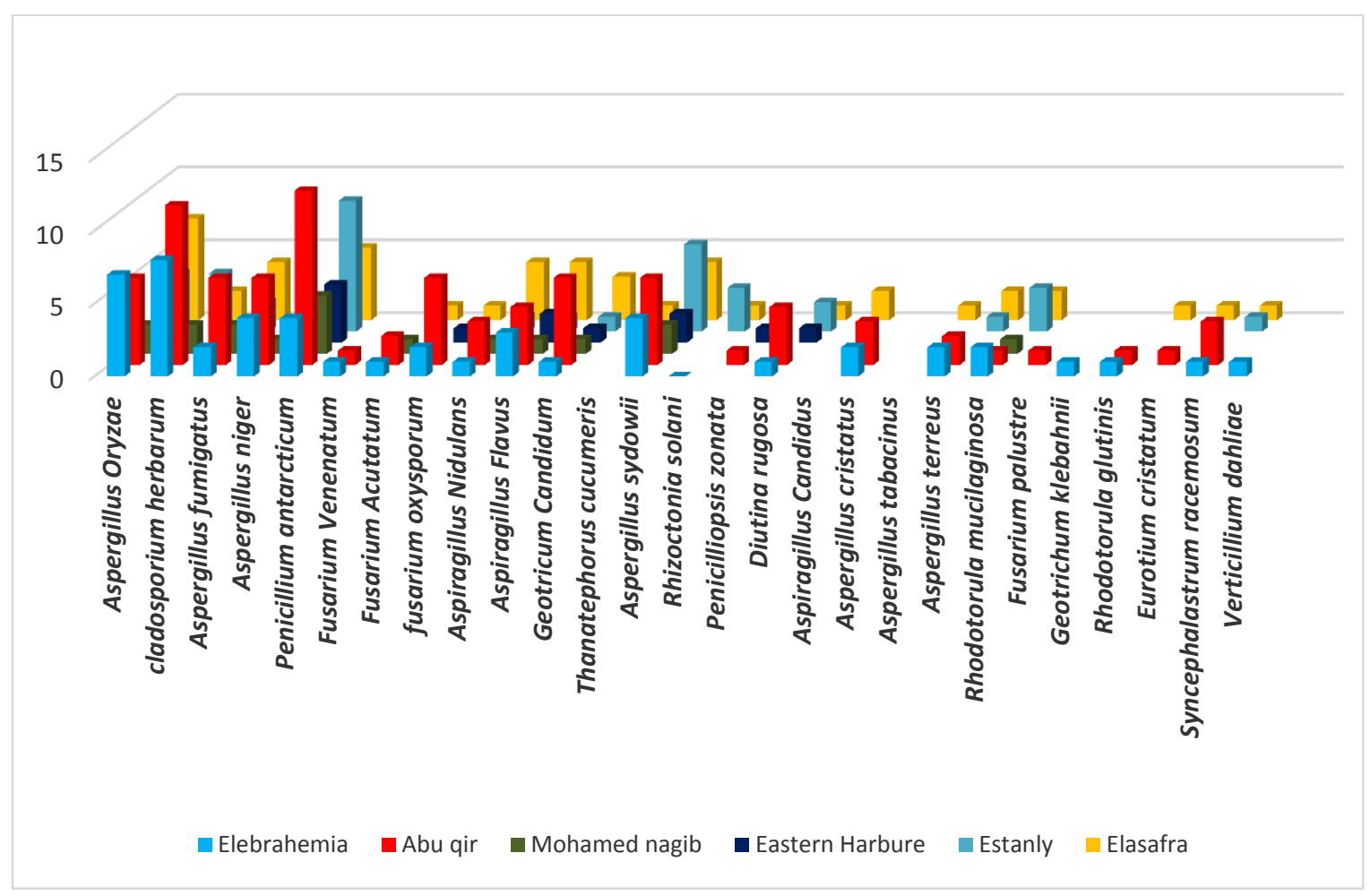

Fig. 5. Distribution of isolated species at different locations of the eastern coast of Alexandria, Egypt. 
Moreover, the distribution of the isolated species from variance marine sources is shown in (Fig. 6). The results showed that Aspergillus oryzae, Cladosporium herbarum, Penicillium antarcticum, aspergillus flavus, Aspergillus fumigatus and Aspergillus sydowii were the most distributed species, and they were isolated from all marine sources, while Rhodotorula mucilaginosa, Rhodotorula glutinis, Eurotium cristatum, Syncephalastrum racemosum, and Verticillium dahliae were isolated only from sediment, Fusarium palustre was isolated from the wood, while Geotrichum klebahnii were isolated only from algae. The total 252 OTUs corresponded to three fungal phyla (Ascomycota, Basidiomycota, and Mucoromycota), the most dominant phylum was the Ascomycota (90.8\% OTUs), followed by the Basidiomycota (6.7\% OTUs). A small proportion was assigned to the Mucoromycota (2.3\% OTUs). In our study, we were investigated marine fungi through the cultivation of fungal isolates and subsequent molecular analyses as in another study (Rämä et $\boldsymbol{a l}$. , 2014) with other parts of the North Norwegian coast has recovered a less or more similar fungal OTUs results, where Dikarya dominates.

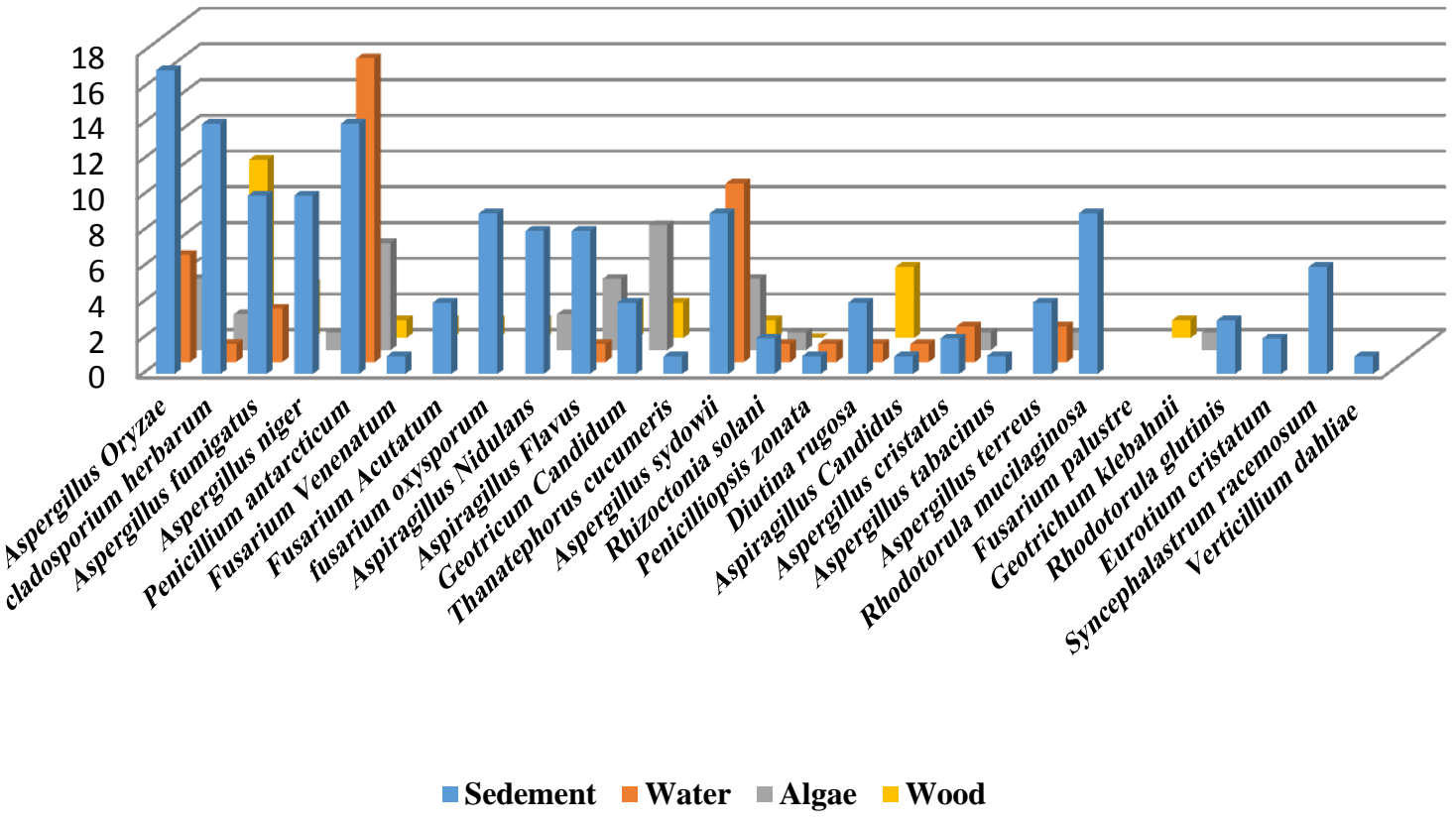

Fig. 6. Distribution of isolated species from variance marine sources of the eastern coast of Alexandria, Egypt. 


\subsection{Robustness of species richness}

Estimators of species richness were applied to obtain reliable species numbers to be expected with the conventional cultivation techniques (Pozo et al., 2011). Estimates of the total species number clearly showed that our observed richness values likely underestimated total richness (Table 4). Estimates of OTUs of fungal richness overlapped our observed values (Morris et al., 2014) suggesting that these observations are robust.

Table 4. Observed and estimated the total number of OTUs by using four different estimators Chao (Chao, 1987), first-order Jackknife, second-order Jackknife, and Bootstrap (Smith and van Belle, 1984).

\begin{tabular}{lc|c}
\hline \multicolumn{2}{l|}{ Original data set: } & SD \\
\hline Observed OTUs & 27 & \\
\hline Chao 2: & 27 & 0.305 \\
\hline Jackknife 1: & 27 & 0 \\
\hline Jackknife 2: & 23.44 & NA \\
\hline Bootstrap: & 27.61 & NA \\
\hline Bootstrap replicates, & means: & SD \\
\hline Chao 2: & 27.09 & 1.73 \\
\hline Jackknife 1: & 28.03 & 1.70 \\
\hline Jackknife 2: & 27.66 & 3.15 \\
\hline Bootstrap: & 27.60 & 1.13 \\
\hline
\end{tabular}

(SD) stands for standard deviation.

\subsection{Biodiversity measures}

Quantitative expressions of community structure are known as biodiversity measures. The number of species of a given taxon (species richness) and how similar species are in their abundances (evenness) are important measures of diversity (Magurran, 2004). For estimating the biodiversity measures present many indices available that emphasize different components of diversity so that no unified biodiversity index is available (Clarke and Warwick, 2001). So, in our study, we were measured fungal biodiversity by most of the indices available for estimating these measures. The fungal samples sediment, Abu Qir, Elebrahemia, Elasafra, with 25, 21, 20, and 20 OTUs, respectively, showed the highest richness of fungal communities. Eastern Harbor, Mohamed Nagib, wood, water, algae, and Estanly samples reveal 8, 11, 11, 12, 12, and 13 OTUs, respectively. Indices of Shannon $(\mathrm{H})$ for diversity and Simpson (1-D) for evenness, and data were broadly in agreement with those reported with the richness index (Table 5).

The Shannon index has represented all species in a sample and that they are randomly sampled which the highest value is found in sediment (Shannon index $=2.9$ ) and similar in both localities Abu Qir and Elasafra (Shannon index=2.77). Diversity regarded as evenness was found to be high in Sediment (Simpson's index: 0.93) and similar in 
both localities Abu Qir and Elasafra (Simpson's index: =0.92). According to Buzas and Gibson's evenness (Evenness_e $\mathrm{e}^{\wedge} \mathrm{H} / \mathrm{S}$ ), the water (Evenness_e^ $\mathrm{H} / \mathrm{S}=0.56$ ) and wood (Evenness_e $\mathrm{e}^{\wedge} \mathrm{H} / \mathrm{S}=0.68$ ) samples proved to be less diverse which, as mentioned before, decreases in the value of the Shannon diversity index. Margalef index revealed the highest value for species richness in Elasafra (Margalef $=4.9$ ) followed by Elebrahemia (Margalef $=4.88$ ). The Brillouin index agrees that the highest diversity is found in Sediment (Brillouin = 2.64) followed by Abu Qir (Brillouin = 2.44) but the Fisher_alpha index shows a higher abundance of rare species in Elasafra (Fisher_alpha $=12.87$ ) than in Elebrahemia (Fisher_alpha $=12.61$ ). Calculated diversity indices revealed Menhinick index was found to be high in Elasafra (Menhinick $=2.88$ ) followed by Elebrahemia (Menhinick $=2.85$ ). the equitability index revealed the highest value for species evenness in Mohamed Nagib (Equitability=0.94) followed by Elasafra (Equitability=0.92). BergerParker and Chao-1 were also calculated (Table 5).

Data in Fig. 7, clearly shows that fungal marine samples (sediment and Elebrahemia) were detached from (Elasafra) and (Abu Qir) samples, thus suggesting that their marine fungal communities were different. Wood samples were replicated to verify that the sampling effort is reliable. Results in Fig. 8, showed that both replicates were grouped and present in the same branch cluster. As we expected wood is the most different which form various clusters of similarity. These different similarity values may be due to nature, properties, and the long period of fungus isolation from the wood. Further clusters were formed like Eastern Harbor and Mohamed Nagib; water and Estanly; sediment and Abu Qir; Elasafra; and Elebrahemia.

Table 5. Means of total fungal OTUs, diversity indices of samples from different locations and sources.

\begin{tabular}{cllllllllll}
\hline $\begin{array}{c}\text { Locations and } \\
\text { sources } \\
\text { Diversity }\end{array}$ & $\begin{array}{l}\text { Elebr- } \\
\text { hemia }\end{array}$ & $\begin{array}{l}\text { Abu } \\
\text { Qir }\end{array}$ & $\begin{array}{l}\text { Mohmd } \\
\text { Nagib }\end{array}$ & $\begin{array}{l}\text { Eastern } \\
\text { Harbor }\end{array}$ & Estanly & Elasfra & $\begin{array}{l}\text { Sedim- } \\
\text { ent }\end{array}$ & Water & Algae & Wood \\
\hline OTUs richness & 20 & 21 & 11 & 8 & 13 & 20 & 25 & 12 & 12 & 11 \\
\hline
\end{tabular}

(S)

\begin{tabular}{lllllllllll}
\hline $\begin{array}{l}\text { Total number of } \\
\text { individuals }\end{array}$ & 49 & 86 & 18 & 13 & 38 & 48 & 145 & 46 & 34 & 27 \\
\hline Dominance_D & 0.082 & 0.074 & 0.1173 & 0.1716 & 0.124 & 0.075 & 0.065 & 0.211 & 0.126 & 0.190 \\
\hline Simpson_1-D & 0.917 & 0.925 & 0.8827 & 0.828 & 0.875 & 0.925 & 0.934 & 0.788 & 0.873 & 0.809 \\
\hline Shannon_H & 2.726 & 2.775 & 2.274 & 1.925 & 2.296 & 2.773 & 2.9 & 1.915 & 2.239 & 2.013 \\
\hline Evenness_e^H/S & 0.7637 & 0.7635 & 0.8837 & 0.857 & 0.7642 & 0.8007 & 0.7271 & 0.5658 & 0.7818 & 0.680 \\
\hline Brillouin & 2.258 & 2.443 & 1.691 & 1.384 & 1.902 & 2.293 & 2.642 & 1.621 & 1.84 & 1.596 \\
\hline Menhinick & 2.857 & 2.264 & 2.593 & 2.219 & 2.109 & 2.887 & 2.076 & 1.769 & 2.058 & 2.117 \\
\hline Margalef & 4.882 & 4.49 & 3.46 & 2.729 & 3.299 & 4.908 & 4.822 & 2.873 & 3.119 & 3.034 \\
\hline Equitability_J & 0.91 & 0.9114 & 0.9484 & 0.9258 & 0.895 & 0.925 & 0.901 & 0.770 & 0.900 & 0.839 \\
\hline Fisher_alpha & 12.61 & 8.856 & 12.01 & 8.855 & 6.975 & 12.87 & 8.708 & 5.277 & 6.61 & 6.92 \\
\hline Berger-Parker & 0.163 & 0.139 & 0.2222 & 0.3077 & 0.236 & 0.145 & 0.117 & 0.369 & 0.205 & 0.370 \\
\hline Chao-1 & 26.00 & 26.00 & 14.00 & 11.33 & 16.33 & 27.20 & 28.75 & 17.00 & 15.33 & 16.00 \\
\hline
\end{tabular}


As a further perspective, the fungal world is full of many interesting applications which encourage the researchers to attempt to recover new strains/isolates in particular that belong to extreme environments, fungi could contribute to finding new substances that act as antimicrobials in a similar finding with plants (Suleiman, 2020) to tackle the emerging problem of bacterial resistance to antibiotics (Suleiman, 2017), production of valuable substances such as biodiesel (Hashem et al., 2019), PUFAs from the oleaginous fungi (Suleiman et al., 2018a; Suleiman et al., 2018b). Our future studies will deal with the extraction of some fungal enzymes with inspiring biotechnological applications.

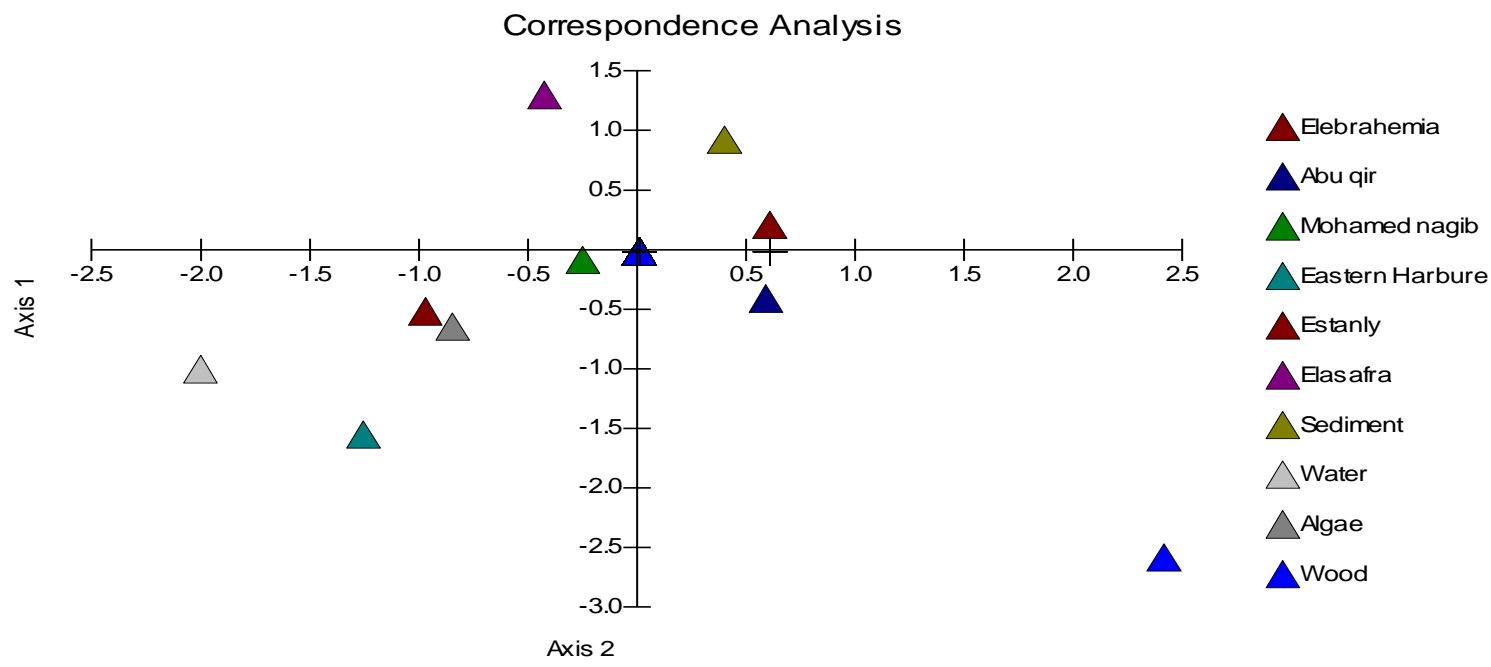

Fig. 7. Correspondence analysis of the different fungal communities in different locations and sources of the eastern coast of Alexandria, Egypt. Marine samples are positioned along the two axes.

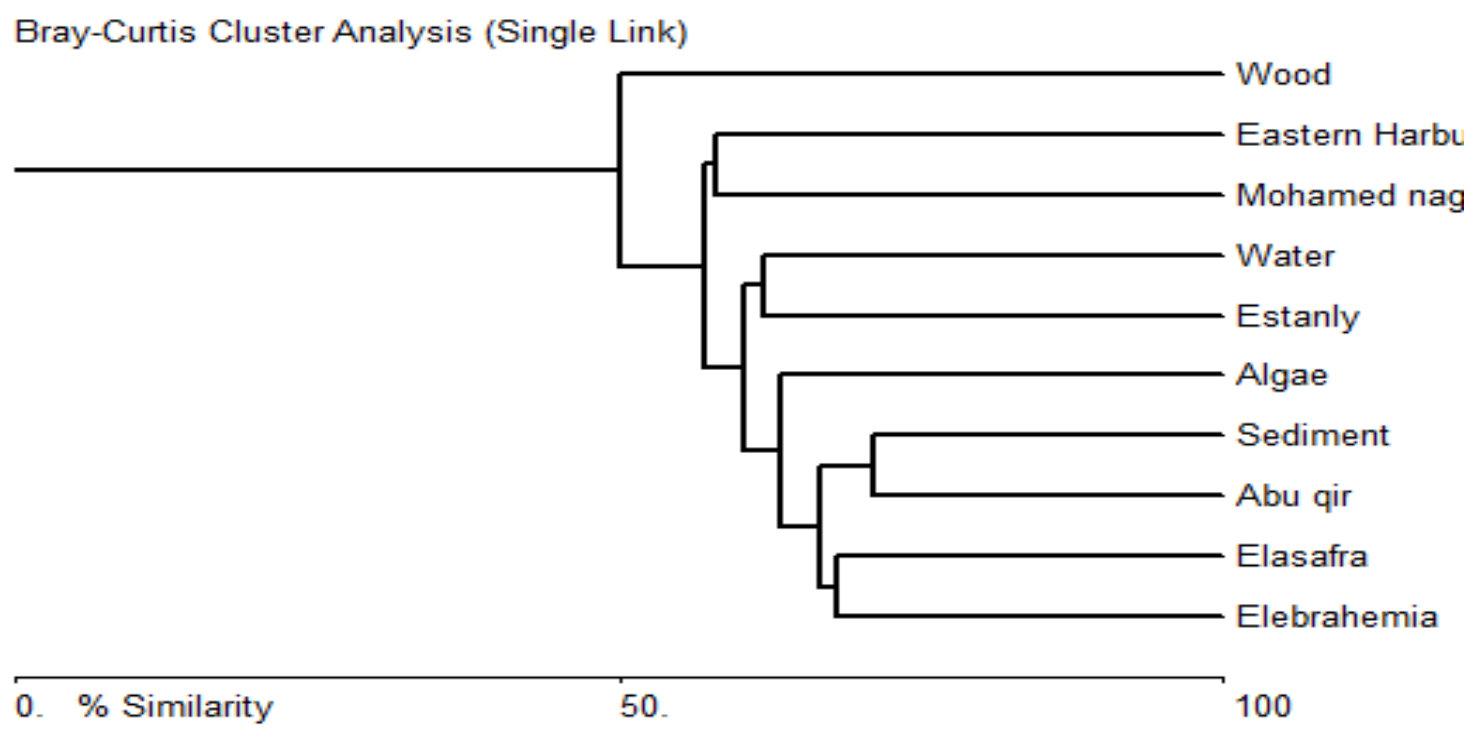

Fig. 8. Bray-Curtis cluster analysis of different fungal communities in different locations and sources of the marine eastern coast of Alexandria, Egypt. 


\section{CONCLUSION}

According to our findings, the biodiversity measures of marine fungal isolates were isolated from sea sediment, water, algae, and wood samples present many indices available that emphasize different components of diversity so that, in our study, we had measured fungal biodiversity by most of the indices available for estimating these measures. The fungal samples from sediment, Abu Qir, Elebrahemia, Elasafra, with 25, 21, 20, and 20 OTUs, respectively, showed the highest richness of fungal communities. Estimates of total species number showed that our observed richness values likely underestimated total richness. All marine fungal isolates from this work will be an integral part of future work to produce efficient enzymes which can be used for industry.

\section{REFERENCES}

Abdel-Halim, A. M. and Aly-Eldeen, M. A. (2016). Characteristics of Mediterranean Sea water in vicinity of Sidikerir Region, west of Alexandria, Egypt. The Egyptian Journal of Aquatic Research, 42(2): 133-140.

Abdelmongy, A. S. and El-Moselhy, K. M. (2015). Seasonal variations of the physical and chemical properties of seawater at the Northern Red Sea, Egypt. Open journal of ocean and coastal sciences, 2(1): 1-17.

Abdel-Razek, A. S.; El-Sheikh, H. H.; Suleiman, W. B.; Taha, T. H. and Mohamed, M. K. (2020). Bioelimination of phenanthrene using degrading bacteria isolated from petroleum soil: safe approach. Desalination and Water Treatment, 181: 131140.

Abd-Elsalam, K. A.; Asran-Amal, A. and El-Samawaty, A. M. A. (2007). Isolation of high-quality DNA from cotton and its fungal pathogens. Journal of Plant Diseases and protection, 114(3): 113-116.

Abdel-Wahab, M. A.; Jones; E. G.; Bahkali, A. H. and El-Gorban, A. M. (2019). Marine fungi from Red Sea mangroves in Saudi Arabia with Fulvocentrum rubrum sp. nov.(Torpedosporales, Ascomycota). Nova Hedwigia, 108(3-4), 365377.

Ali, E. M. and Khairy, H. M. (2016). Environmental assessment of drainage water impacts on water quality and eutrophication level of Lake Idku, Egypt. Environmental pollution, 216: 437-449.

Amer, M. S.; Abd Ellatif, H. H.; Hassan, S. W.; Aboelela, G. M. and Gad, A. M. (2019). Characterization of some fungal strains isolated from the Eastern coast of Alexandria, Egypt, and some applications of Penicillium crustosum. The Egyptian Journal of Aquatic Research, 45(3): 211-217.

Arif, M.; Zaidi, N. W.; Haq, Q. M. R.; Singh, Y. P.; Khan, S. and Singh, U. S. (2013). Molecular phylogeny and pathotyping of F usarium solani: a causal agent of D albergia sissoo decline. Forest Pathology, 43(6): 478-487. 
Baka, Z.; El-Sheikh, H.; Bakry, W. and Helmy, E. (2015). Physiological and molecular responses of fusarium moniliforme treated with heavy metals. African Journal of Mycology and Biotechnology, 20(2): 1-22.

Bennett, A. E. and Classen, A. T. (2020). Climate change influences mycorrhizal fungal-plant interactions, but conclusions are limited by geographical study bias. Ecology, 101(4), e02978.

Blaxter, M.; Mann, J.; Chapman, T.; Thomas, F.; Whitton, C.; Floyd, R. and Abebe, E. (2005). Defining operational taxonomic units using DNA barcode data. Philosophical Transactions of the Royal Society B: Biological Sciences, 360(1462): 1935-1943.

Blunt, J. W.; Copp, B. R.; Keyzers, R. A.; Munroa, M. H. and Prinsepd, M. R. (2016). Natural product reports. Nat Prod Rep, 33: 382-431.

Bremer, G. (2000). Isolation and culture of thraustochytrids. Fungal Diversity Research Series, 1: 49-61.

Cavicchioli, R.; Ripple, W. J.; Timmis, K. N.; Azam, F.; Bakken, L. R.; Baylis, M., ... and Webster, N. S. (2019). Scientists' warning to humanity: microorganisms and climate change. Nature Reviews Microbiology, 17(9): 569-586.

Clarke, K. R. and Warwick, R. M. (2001). A further biodiversity index applicable to species lists: variation in taxonomic distinctness. Marine ecology Progress series, 216: 265-278.

Crous, P. W.; Verkley, G. J.; Groenewald, J. Z. and Samson, R. A. (2009). Fungal biodiversity. CBS Laboratory Manual Series 1: 1-269.

Das, K.; Ghosh, A.; Bhatt, R. P.; Chakraborty, D.; Hofstetter, V. and Buyck, B. (2017). Fungal Biodiversity Profiles 41-50 Mycologie.

Domsch, K. H., Gams, W. and Anderson, T. H. (1980). Compendium of soil fungi. Volume 1. (Academic Press (London) Ltd.).

Duarte, K.; Rocha-Santos, T. A.; Freitas, A. C. and Duarte, A. C. (2012). Analytical techniques for discovery of bioactive compounds from marine fungi. TrAC Trends in Analytical Chemistry, 34: 97-110.

Edgcomb, V. P.; Beaudoin, D.; Gast, R.; Biddle, J. F. and Teske, A. (2011). Marine subsurface eukaryotes: the fungal majority. Environmental microbiology, 13(1): 172-183.

El-Sheikh, H.; Baka, Z.; Helmy, E. A. and Bakry, W. (2014). Impact of some heavy metals on ultrastructure and metabolic profile of $\mathrm{f}$. Moniliforme. African Journal of Mycology and Biotechnology, 19(3): 1-16.

Frąc, M.; Hannula, S. E.; Bełka, M. and Jędryczka, M. (2018). Fungal biodiversity and their role in soil health. Frontiers in Microbiology, 9: 707.

Gao, C.; Shi, N. N.; Liu, Y. X.; Peay, K. G., Zheng, Y.; Ding, Q.; ... and Guo, L. D. (2013). Host plant genus- level diversity is the best predictor of ectomycorrhizal 
fungal diversity in a Chinese subtropical forest. Molecular Ecology, 22(12): 34033414.

Gladfelter, A. S.; James, T. Y. and Amend, A. S. (2019). Marine fungi. Current Biology, 29(6): R191-R195.

Gow, N. A. and Gadd, G. M. (Eds.). (2007). Growing fungus. Springer Science \& Business Media .

Grasshoff, K.; Kremling, K. and Ehrhardt, M. (Eds.). (2009). Methods of seawater analysis. John Wiley \& Sons.

Grossart, H. P.; Van den Wyngaert, S.; Kagami, M.; Wurzbacher, C.; Cunliffe, M. and Rojas-Jimenez, K. (2019). Fungi in aquatic ecosystems. Nature Reviews Microbiology, 17(6): 339-354.

Guo, X.; Zhang, Q.; Zhang, X.; Zhang, J. and Gong, J. (2015). Marine fungal communities in water and surface sediment of a sea cucumber farming system: habitat-differentiated distribution and nutrients driving succession. Fungal Ecology, 14, 87-98.

Hammer, Ø.; Harper, D. A. and Ryan, P. D. (2001). PAST: Paleontological statistics software package for education and data analysis. Palaeontologia electronica, 4(1): 9.

Hashem, A. H.; Hasanin, M. S.; Khalil, A. M. A. and Suleiman, W. B. (2019). Ecogreen conversion of watermelon peels to single cell oils using a unique oleaginous fungus: Lichtheimia corymbifera AH13. Waste and Biomass Valorization, 1-12.

Hashem, A. H.; Suleiman, W. B.; Abu-elreesh, G.; Shehabeldine, A. M. and Khalil, A. M. A. (2020). Sustainable lipid production from oleaginous fungus Syncephalastrum racemosum using synthetic and watermelon peel waste media. Bioresource Technology Reports, 12: 100569.

Hashem, A. H.; Suleiman, W. B.; Abu-Elrish, G. M. and El-Sheikh, H. H. (2021). Consolidated bioprocessing of sugarcane bagasse to microbial oil by newly isolated Oleaginous Fungus: Mortierella wolfii. Arabian Journal for Science and Engineering, 46(1): 199-211.

Hassett, B. T.; Borrego, E. J.; Vonnahme, T. R.; Rämä, T.; Kolomiets, M. V. and Gradinger, R. (2019). Arctic marine fungi: biomass, functional genes, and putative ecological roles. The ISME journal, 13(6): 1484-1496.

Hassett, B. T.; Vonnahme, T. R.; Peng, X.; Jones, E. G. and Heuzé, C. (2020). Global diversity and geography of planktonic marine fungi. Botanica Marina, 63(2): 121139.

Hibbett, D. S.; Binder, M.; Bischoff, J. F.; Blackwell, M.; Cannon, P. F.; Eriksson, O. E.; ...and Zhang, N. (2007). A higher-level phylogenetic classification of the Fungi. Mycological research, 111(5): 509-547. 
Hussain, O. A.; Sobhy, H. M.; Hathout, A. S. and Fouzy, A. S. M. (2018). Isolation and molecular identification of Fusarium fungi from some Egyptian grains. Asian Journal of Plant Sciences, 17(4): 182-190.

Ivanov, V. Y.; Bras, R. L. and Curtis, D. C. (2007). A weather generator for hydrological, ecological, and agricultural applications. Water resources research, 43(10).

Jarvis, B. (1973). Comparison of an improved rose bengal- chlortetracycline agar with other media for the selective isolation and enumeration of moulds and yeasts in foods. Journal of Applied Bacteriology, 36(4): 723-727.

Jebaraj, C. S.; Raghukumar, C.; Behnke, A. and Stoeck, T. (2010). Fungal diversity in oxygen-depleted regions of the Arabian Sea revealed by targeted environmental sequencing combined with cultivation. FEMS Microbiology Ecology, 71(3): 399412.

Jones, E. B. G. (1995). Ultrastructure and taxonomy of the aquatic ascomycetous order Halosphaeriales. Canadian Journal of Botany, 73(S1): 790-801.

Jones, E. G. and Pang, K. L. (2012). Tropical aquatic fungi. Biodiversity and conservation, 21(9): 2403-2423.

Kohlmeyer J, Volkmann-Kohlmeyer B. (1991) Illustrated key to the filamentous higher marine fungi. Botanica Marina. 34:1-61.

Kuipers, B.; van Noort, G. J.; Vosjan, J. and Herndl, G. J. (2000). Diel periodicity of bacterioplankton in the euphotic zone of the subtropical Atlantic Ocean. Marine Ecology Progress Series, 201: 13-25.

Kükrer, S. and Mutlu, E. (2019). Assessment of surface water quality using water quality index and multivariate statistical analyses in Saraydüzü Dam Lake, Turkey. Environmental monitoring and assessment, 191(2): 71.

Lee, N. L. Y.; Huang, D.; Quek, Z. B. R.; Lee, J. N., and Wainwright, B. J. (2019). Mangrove-associated fungal communities are differentiated by geographic location and host structure. Frontiers in microbiology, 10: 2456.

Magurran, A. E. (2004). Measuring biological diversity blackwell science. Biological diversity: frontiers in measurement and assessment. Oxford, 105.

Morris, E. K.; Caruso, T.; Buscot, F.; Fischer, M.; Hancock, C.; Maier, T. S.; ... and Rillig, M. C. (2014). Choosing and using diversity indices: insights for ecological applications from the German Biodiversity Exploratories. Ecology and evolution, 4(18): 3514-3524.

Nagahama, T.; Hamamoto, M.; Nakase, T. and Horikoshi, K. (2003). Rhodotorula benthica sp. nov. and Rhodotorula calyptogenae sp. nov., novel yeast species from animals collected from the deep-sea floor, and Rhodotorula lysiniphila sp. nov., which is related phylogenetically. International journal of systematic and evolutionary microbiology, 53(3): 897-903. 
Nagano, Y.; Millar, B. C.; Goldsmith, C. E.; Walker, J. M.; Elborn, J. S.; Rendall, J. and Moore, J. E. (2008). Development of selective media for the isolation of yeasts and filamentous fungi from the sputum of adult patients with cystic fibrosis (CF). Journal of Cystic Fibrosis, 7(6): 566-572.

Nessim, R. B.; Masoud, M. S. and Maximous, N. N. (2005). Water characteristics of Alexandria hot spots. Egyptian journal of aquatic research, 31: 25-37.

Nilsson, R. H.; Tedersoo, L.; Abarenkov, K.; Ryberg, M.; Kristiansson, E.; Hartmann, M.;... and Kõljalg, U. (2012). Five simple guidelines for establishing basic authenticity and reliability of newly generated fungal ITS sequences. MycoKeys, 4: 37.

Okasanen, J.; Blanchet, F. G.; Kindet, R.; Legendre, P.; Minchin, P. R.; O'Hara, R. B.; and Wagner, H. (2012). vegan: Community Ecology Package, R package version 2.0-4.

Orsi, W.; Biddle, J. F. and Edgcomb, V. (2013). Deep sequencing of subseafloor eukaryotic rRNA reveals active fungi across marine subsurface provinces. PloS one, 8(2): e56335.

Overy, D. P.; Rämä, T.; Oosterhuis, R.; Walker, A. K. and Pang, K. L. (2019). The neglected marine fungi, sensu stricto, and their isolation for natural products' discovery. Marine Drugs, 17(1): 42.

Pozo, M. I.; Herrera, C. M. and Bazaga, P. (2011). Species richness of yeast communities in floral nectar of southern Spanish plants. Microbial Ecology, 61(1): 82-91.

Raghukumar, S. (2017). The marine environment and the role of fungi. In Fungi in coastal and oceanic marine ecosystems. Cham, (pp. 17-38).

Rämä, T.; Nordén, J.; Davey, M. L.; Mathiassen, G. H.; Spatafora, J. W. and Kauserud, H. (2014). Fungi ahoy! Diversity on marine wooden substrata in the high North. Fungal Ecology, 8: 46-58.

Richards, T. A.; Jones, M. D.; Leonard, G. and Bass, D. (2012). Marine fungi: their ecology and molecular diversity. Annual review of marine science, 4: 495-522.

Saad, A. S.; Massoud, M. A.; Amer, R. A. and Ghorab, M. A. (2017). Assessment of the Physicochemical Characteristics and Water Quality Analysis of Mariout Lake, Southern of Alexandria, Egypt. Journal of Environmental and Analytical Toxicology, 7(1): 421.

Schmit, J. P. (2003). A checklist of mangrove-associated fungi, their geographical distribution and known host plant. Mycotaxon, 85: 423-477.

Suleiman, W., El-bous, M., Ibrahim, M. and El Baz, H. (2019). In vitro evaluation of Syzygium aromaticum L. ethanol extract as biocontrol agent against postharvest tomato and potato diseases. Egyptian Journal of Botany, 59(1): 81-94. 
Suleiman, W. B. (2020). In vitro estimation of superfluid critical extracts of some plants for their antimicrobial potential, phytochemistry, and GC-MS analyses. Annals of Clinical Microbiology and Antimicrobials, 19(1): 1-12.

Suleiman, W. B.; El-Sheikh, H. H.; Abu-Elreesh, G. and Hashem, A. H. (2018a). Recruitment of Cunninghamella echinulata as an Egyptian isolate to produce unsaturated fatty acids. Research Journal Of Pharmaceutical Biological And Chemical Sciences, 9(1): 764-774.

Suleiman, W.; El-Skeikh, H.; Abu-Elreesh, G. and Hashem, A. (2018b). Isolation and screening of promising oleaginous Rhizopus sp and designing of Taguchi method for increasing lipid production. J. Innov. Pharm. Biol. Sci, 5: 8-15.

Tisthammer, K. H.; Cobian, G. M. and Amend, A. S. (2016). Global biogeography of marine fungi is shaped by the environment. Fungal Ecology, 19: 39-46.

White, T. J.; Bruns, T.; Lee, S. J. W. T. and Taylor, J. (1990). Amplification and direct sequencing of fungal ribosomal RNA genes for phylogenetics. PCR protocols: a guide to methods and applications, 18(1): 315-322.

Yarden, O. (2014). Fungal association with sessile marine invertebrates. Frontiers in Microbiology, 5: 228.

Zyadah, M.; Ibrahim, M. and Madkour, A. (2004). Impact of environmental parameters on benthic invertebrates and zooplankton biodiversity of the Eastern region of Delta coast at Damietta, Egypt. Egyptian Journal of Aquatic Biology and Fisheries, 8(4): 37-52. 